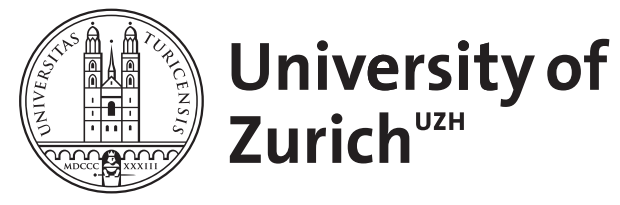

Zurich Open Repository and Archive

University of Zurich

University Library

Strickhofstrasse 39

CH-8057 Zurich

www.zora.uzh.ch

Year: 2015

\title{
Distinctive or diverse? Conceptualizing ancient Israelite religion in its southern Levantine setting
}

Uehlinger, Christoph

DOI: https://doi.org/10.1628/219222715X14343676549106

Posted at the Zurich Open Repository and Archive, University of Zurich ZORA URL: https://doi.org/10.5167/uzh-117999

Journal Article

Published Version

Originally published at:

Uehlinger, Christoph (2015). Distinctive or diverse? Conceptualizing ancient Israelite religion in its southern Levantine setting. Hebrew Bible and Ancient Israel, 4(1):1-24.

DOI: https://doi.org/10.1628/219222715X14343676549106 


\section{Hebrew Bible and \\ Ancient Israel}

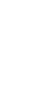

Volume 4 2015

Commonalities and Differences: Religion(s) of Iron Age II Israel and Judah in Context

Christoph Uehlinger

Distinctive or diverse? Conceptualizing ancient Israelite religion in its southern Levantine setting 1-24

Amihai Mazar

Religious Practices and Cult Objects during the Iron Age IIA at Tel Rehov and their Implications regarding Religion in Northern Israel 25-55

Omer Sergi

State Formation, Religion and "Collective Identity" in the Southern Levant 56-77

\section{Seth L. Sanders}

When the Personal Became Political:

An Onomastic Perspective on the Rise of Yahwism 78-105

Terje Stordalen

Horse Statues in Seventh Century Jerusalem:

Ancient Social Formations and the Evaluation

of Religious Diversity 106-132

\section{New Projects}

Oded Lipschits, Manfred Oeming, Yuval Gadot, Interdisciplinary Research of Assyrian Siege Ramps The Case of Tel Azekah 135-143

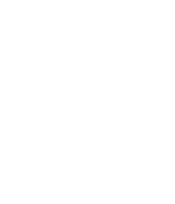

Mohr Siebeck 


\section{Hebrew Bible and Ancient Israel}

Herausgegeben von Gary N. Knoppers (Notre Dame IN), Oded Lipschits (Tel Aviv), Carol A. Newsom (Atlanta GA) und Konrad Schmid (Zürich) Redaktion: Phillip Michael Lasater (Zürich)

Die Annahme zur Veröffentlichung erfolgt schriftlich und unter dem Vorbehalt, dass das Manuskript nicht anderweitig zur Veröffentlichung angeboten wurde. Mit der Annahme zur Veröffentlichung überträgt der Autor dem Verlag das ausschließliche Verlagsrecht für die Publikation in gedruckter und elektronischer Form. Weitere Informationen dazu und zu den beim Autor verbleibenden Rechten finden Sie unter www.mohr.de/hebai. Ohne Erlaubnis des Verlags ist eine Vervielfältigung oder Verbreitung der ganzen Zeitschrift oder von Teilen daraus in gedruckter oder elektronischer Form nicht gestattet. Bitte wenden Sie sich an rights@mohr.de.

Redaktionsadresse

Professor Dr. Konrad Schmid

Theologische Fakultät der Universität Zürich

Kirchgasse 9

$\mathrm{CH}-8001$ Zürich

Switzerland

E-mail: hebai@theol.uzh.ch

Online-Volltext

Im Abonnement für Institutionen und Privatpersonen ist der freie Zugang zum Online-Volltext enthalten. Institutionen mit mehr als 20.000 Nutzern bitten wir um Einholung eines Preisangebots direkt beim Verlag. Kontakt: elke. brixner@mohr.de. Um den Online-Zugang für Institutionen/Bibliotheken einzurichten, gehen Sie bitte zur Seite: www.ingentaconnect.com/register/ institutional. Um den Online-Zugang für Privatpersonen einzurichten, gehen Sie bitte zur Seite: www.ingentaconnect.com/register/personal

Verlag: Mohr Siebeck GmbH \& Co. KG, Postfach 2040, 72010 Tübingen Vertrieb erfolgt über den Buchhandel.

(C) 2015 Mohr Siebeck GmbH \& Co. KG, Tübingen

Die Zeitschrift und alle in ihr enthaltenen einzelnen Beiträge und Abbildungen sind urheberrechtlich geschützt. Jede Verwertung außerhalb der engen Grenzen des Urheberrechtsgesetzes ist ohne Zustimmung des Verlags unzulässig und strafbar. Das gilt insbesondere für Vervielfältigungen, Übersetzungen, Mikroverfilmungen und die Einspeicherung und Verarbeitung in elektronischen Systemen.

Satz: Martin Fischer, Tübingen.

Druck: Gulde-Druck, Tübingen.

ISSN 2192-2276 (Gedruckte Ausgabe)

ISSN 2192-2284 (Online-Ausgabe) 


\section{Christoph Uehlinger}

\section{Distinctive or diverse? Conceptualizing ancient Israelite religion in its southern Levantine setting}

In an increasingly globalized world, the concepts of "culture" and "religion" have regained major significance in both public and scholarly discussions of group identities. They heavily impact the marking of symbolic and interactional boundaries between, as well as within, contemporary societies and communities. The contemporary world offers unprecedented potential for movements of people, goods, and ideas; conversely, technological and other means to limit such movements have also reached an unprecedented stage of sophistication. Both of these developments participate in processes of worldwide social change. They betray the difficulties facing long privileged, Western societies (especially in 'Old Europe') in their need to accommodate new social realities that can only be partially controlled via local policies. Moral and legal principles conceived to pacify European societies and considered by many today to express values basic to Western liberal democracies (e. g., universal human rights, such as freedom of religion) are subject to considerable debate in these Western contexts. Their challenge is to negotiate a way between, on the one hand, gradually exhausting their own religious past and, on the other hand, the "newly" arriving, alternative religious beliefs and practices that Europe considered "foreign" just a generation ago.

One of the greater traditions (Islam) is often singled out in Western discourse as particularly problematic and resistant to (if not incompatible with) European or Western values and achievements, such as the Enlightenment and its shaping of modernity. Having served Cold War politics and rhetoric from the end of World War II to the fall of the Soviet Union, the dichotomy of East vs. West has been refashioned in terms of religion and civilizations, a change of paradigm epitomized in Samuel Huntington's The Clash of Civilizations and the Remaking of World Order, ${ }^{1}$ the events of September 11, and the current atrocities by radical Islamist organizations. Unlike the earlier dichotomy, many today view each of these two poles as corresponding to

1 S. Huntington, The Clash of Civilizations and the Remaking of World Order (New York: Simon and Schuster, 1996). 
specific religious traditions, so that the so-called Judaeo-Christian tradition and Islam stand in mutual opposition. Such rhetoric reifies and essentializes both ends, passing over the complexities of historical affiliations and entanglements. But needless to say, radical movements that consider cultural and religious disjunction as a necessary step toward political and social salvation easily parasitize this kind of rhetoric.

General as these observations may be, they nonetheless highlight the wider context of current social-scientific and historical research on cultural and religious commonalities and diversity. In society and the academy alike, the late $20^{\text {th }}$ and early $21^{\text {st }}$ centuries have witnessed an escalating concern with defining particular ethnic, cultural, and/or religious identities, having led to numerous claims about the peculiarities, if not the incommensurability, of particular group identities. At the same time, there is a growing awareness that any society, whether territorially or nationally defined, is a pluralistic constituency, since societies host a variety of communities and groups with their cultures and sub-cultures existing alongside one another. Such internal plurality and diversity may be more or less complex, depending on a given society's historical trajectory, and they may be more or less acknowledged and reflected upon in society.

In view of these developments, then, it is not surprising that pluralism, multi-culturalism and diversity have become major catchwords in contemporary social and political debate, ${ }^{2}$ and they have long impacted historical research as well.

To view a society (ancient or modern) or some of its components as altogether diverse, multi-cultural or pluralistic raises the following theoretical questions: How do scholars and the societies they study construe diversity, and through which concepts and taxonomies do they do so? How do they recognize and attribute relative weight to that which distinguishes social groups from each other, whether "objectively" in the eyes of "neutral" observers or "perspectivally" in their own eyes or the eyes of others? On what grounds should this or that cultural feature of a particular group be regarded as a diagnostic marker of a specific, cultural identity? Moreover,

2 C. Taylor, Multiculturalism and "The Politics of Recognition" (Princeton: Princeton University Press, 1992); G. Baumann, The Multicultural Riddle: Rethinking National, Ethnic, and Religious Identities (London: Routledge, 1999); E. Ben-Rafael and Y. Sternberg (ed.), World Religions and Multiculturalism: A Dialectic Relation (International Comparative Social Studies 23; Leiden: Brill, 2010); S. Vertovec, The Multiculturalism Backlash: European Discourses, Policies and Practices (London: Routledge, 2009); idem, Migration and Diversity (International Library of Studies on Migration 16; Northampton: Edward Elgar Publishing, 2014); idem (ed.), Routledge International Handbook of Diversity Studies (Routledge International Handbooks; London: Routledge, 2015). 
to what extent might the study of diversity and a focus on distinctive features distort rather than clarify, by neglecting how different groups that live alongside one another share and/or exchange material culture, practices, habits, values, worldview, etc.? How should scholars then balance diversity and commonalities within and between the social aggregates they study? And finally, what place should they attribute to religion when investigating, comparing, grouping or distinguishing contemporary or past societies?

Readers of Hebrew Bible and Ancient Israel will be acquainted with most of these questions, which today are virtually everywhere in the news, in public discussions, in politics, and in academia. Like any other scholarly discipline, the academic study of the Bible (Hebrew or otherwise) and related disciplines focusing on the world that gave rise to the Bible evolve and participate in the present. However ancient their object of study may be, the questions that historians of antiquity pose, the tools they use for analyzing a past world and its legacy in the present (including the Bible) are products not of the scrutinized past itself, but of scholarly tradition, academic communication, current scholarship and hence of the scholars' own present. Whoever considers academia as a peculiar segment of contemporary society will therefore not be surprised that questions related to issues such as identity, distinctiveness, boundary-working vs. social cohesion, and commonality vs. diversity have come to the forefront of biblical and historical scholarship over the past two decades. As a result, fundamental questions about what may or may not have distinguished the culture(s) and religion(s) of ancient Israel and Judah from those of their neighbours are addressed theoretically and in terms that differ markedly from the work of scholars in earlier generations. ${ }^{3}$

This issue of $H e B A I$ is meant to accompany and reflect this process, which is a gradual change in perspective rather than a paradigm shift, as well as to serve the critical self-reflection of interested scholars involved in the study of ancient Levantine religions and societies from the first millennium B.C.E. It contains the work of a private seminar of sorts, sponsored by the University of Zurich, that I convened in June 2014. I am grateful to the participants Amihai Mazar, Seth Sanders, Omer Sergi and Terje Stordalen for their positive and constructive contributions. Their papers in this issue

3 A landmark publication 25 years ago that is still worth consulting if only to measure changes in conceptual outlook is P. Machinist, "Distinctiveness in Ancient Israel: An Essay," in Ah Assyria! Studies in Assyrian History and Ancient Near Eastern Historiography Presented to Hayim Tadmor (ed. M. Cogan and I. Eph'al; Jerusalem: Magnes Press, 1991), 196-212. 
were presented and discussed at our seminar, and were subsequently revised, peer-reviewed, and finalized for publication. ${ }^{4}$

On a very general level, the seminar's epistemological concerns revolved around the following questions:

(1) How do, or how should, scholars describe, categorize and classify both the commonality and diversity of religious practices, beliefs and social arrangements (e. g., infrastructure, institutional basis, participants, and outreach) in the southern Levant during the first millennium B.C.E.?

(2) In the overall picture of attested religious practices, beliefs, and artifacts, what place and status do scholars attribute to what is conventionally called "ancient Israel?" Do scholars operate with a kind of central perspective that places "Israel" at the heart of their concern from the outset? When doing so, are they always critically aware that such a perspective is not simply warranted by sheer factual evidence, but is largely dependent on a Biblecentered scholarly tradition? Do they allow for conceptual spaces that admit alternative approaches and new ways of posing questions, such as taking the geographical concept of Palestine or the Southern Levant ${ }^{5}$ as their starting point?

(3) How do scholars construe the place of ancient Israelite religion within its larger southern Levantine setting? Is their research fundamentally driven by a focused and privileged interest in that religion as an entity of its own, to which other religions provide at best a context, a neighborhood, a stage, or a background? Or do they accommodate alternative approaches that may but need not necessarily lead to conceptually isolating a discrete social, cultural, or religious entity called "ancient Israel," depending on whether or not such conceptual isolation makes sense in view of a particular set of evidence?

(4) How do the histories of Jewish, Christian and Islamic religious traditions (i.e., trajectories of gradually increasing differentiation and pluralization in the "religious field," as understood by P. Bourdieu) influence how biblical scholars and historians of the ancient Levant conceptualize and understand the data they analyze when studying "ancient Israelite religion?" To what extent do they retroject concepts of distinctiveness produced by modern assumptions about these traditions? Or more straightforwardly: To what extent do scholars' socialization, institutional location, and self-

4 I also thank Konrad Schmid and the editorial board of HeBAI for inviting me to serve as editor for this issue, as well as Mark S. Smith with whom I discussed some initial thoughts concerning our seminar early in the summer of 2013 while each of us conducted research at the École Biblique et Archéologique Française de Jérusalem.

5 My personal preference is with the latter term, since it is specific while also implying a necessarily related "beyond" (i. e., the northern Levant). 
understanding guide them when they isolate "ancient Israelite religion" as a discrete taxon within the ancient religion(s) of the first millennium southern Levant?

(5) How do archaeologists, historians, or philologists isolate "religion" in the first place, let alone what they consider a particular religion, when dealing with ancient (or in our case, southern Levantine) societies, cultures, material remains, texts, and literature?

(6) How does contemporary debate with roots in present day social, political and cultural experience (e.g., the issue of diversity) impact the ways that biblical scholars and historians approach and conceptualize their subject?

These sequential questions should invite a large community of scholars (far beyond the seminar participants) to join the debate. Being well aware that the disciplines that HeBAI addresses (i. e., biblical studies, ancient history of the Levant, studies in early Judaism, history of religion[s], etc.) are themselves heterogeneous fields of inquiry, some colleagues will probably be content to consider the first and/or second question. Yet others might take the opposite view and consider the first two questions as interesting only in light of the fourth, fifth, and sixth questions. Not least for that reason, and in order to acknowledge that both biblical studies and other related areas of study are evolving, the four articles constituting the main body of this $H e B A I$ issue are meant to reflect this diversity. It involves a diversity of disciplines (i.e., archaeology, history, epigraphy, biblical studies, critical theory), academic networks and affiliation, scholarly approaches (i. e., from data-focused and descriptive to explanatory and theoretical), personal origins and current locations (Germany, Israel, Norway, Switzerland, and the USA), and academic generations (both senior and younger scholars). ${ }^{6}$ One particular ambition of our gathering and of this issue is that there should be food for thought for many, whether it be those wanting to take stock of new evidence or those wanting to engage problems of theory and explore new ways of asking questions.

6 That no contribution is authored by a female colleague offends any sense of gender equity and scientific rigor (gender being the very first taxon of diversity in Vertovec's Handbook, and rightly so). This absence is an unintended accident for which I apologize. 


\section{"Canaan" vs. "Israel" and other binary classifications}

Since the $19^{\text {th }}$ century, biblical theology and historical reconstructions of "Canaanite" and "Israelite" religion have acknowledged the embeddedness $^{7}$ of ancient Israelite religion within an ancient Near Eastern cultural setting. ${ }^{8}$ Still, they generally end up emphasizing a number of distinctive, if not exclusive, characteristics of "Israelite" (or "biblical") religion, such as monotheism, henotheism or monolatry; a strong orientation toward a single, "national" god and a limited number of state sanctuaries; ritual aniconism; a concept and ethos of "nationhood" based on tribalism and kinshipbased solidarity; and a sense of having been set apart from other nations or, in theological terms, having been elected by Yahweh (if not "God" or "the Lord") into an exclusive covenant relationship, etc. ${ }^{9}$ Framed theologically, Israel was thus set off as an "other," as if the concept of a particular revelation required per se a basic distinctiveness of some kind. Following an important historiographical strand in the Hebrew Bible (which is too narrowly and imprecisely designated "deuteronomistic"), the distinctiveness of that religion and a consciousness of "being different" were long considered to have been vital prerequisites for Israel's raison d'être as a people, a state, or a set apart "nation under God."

Paired with a historical-evolutionary perspective, theological and historiographical narratives presented "ancient Israelite religion" as resulting in a different mindset, if not an altogether higher state of religious consciousness in comparison with the "religions" of Israel's neighbors. A long and much debated question has been: At what stage in the evolution of ancient Israel's religion was this distinctiveness first conceptualized, and when was it was finally consolidated? Indeed, that such an evolution took place between the late second and the end of the first millennium B.C.E. has often been taken

7 Embeddedness here refers to understanding "ancient Israel" as an integral part of first millennium B.C.E. southern Levantine society, culture, and religious setting. This should not be confused with the use of the concept recently criticized by B. Nongbri, where embeddedness refers to "ancient religion" as part of a larger socio-cultural fabric. See B. Nongbri, "Dislodging 'Embedded' Religion: A Brief Note on a Scholarly Trope," Numen 55 (2008): 440-460; idem, Before Religion: A History of a Modern Concept (New Haven: Yale University Press, 2013).

8 The spatial metaphor implies the centrality of and focused attention on a privileged object. This tradition of scholarly discourse still persists today in important scholarly anthologies such as Ancient Near Eastern Texts and Pictures Relating to (sic) the Old Testament, Texte aus der Umwelt des Alten Testaments, or - most explicitly - Contexts of Scripture.

9 To be sure, most of these concepts and beliefs have some resonance in biblical texts, which requires an historical explanation. 
for granted. The evolutionary view was best epitomized in W. F. Albright's From the Stone Age to Christianity, ${ }^{10}$ a book that may now have lost much of its appeal but whose underlying evolutionary assumptions are still at work in much recent writing and teaching on the history of ancient Israelite religion, especially in publications for wider audiences.

Needless to say, this approach largely duplicated the emic perspective of the Bible in its received, canonical forms, and its narrative was in accordance with truth claims shared among both Jews and Christians, who had received, transmitted and preserved over centuries the TaNaKh and the Bible in their various forms. To be sure, contemporary scholars have become more careful with value statements regarding ancient religion in general. After a century of scholarship bringing biblical texts into conversation with ancient literature and archives from Ebla, Mari, Ugarit, Emar and other places, "Canaanite" religion is no more regarded in Albrightian biblicist terms as an abomination, ${ }^{11}$ but it often remains a religious "other" differing considerably from ancient Israelite religion. ${ }^{12}$ Normative agendas (whether religious, academically rationalized, or secularized) or non-explicit assumptions still lurk beneath some of the most recent publications on the history of religion(s) in Israel and the ancient Levant. This raises the question of the extent to which our historical imagination continues to be informed, and can be misled by, such normative assumptions, however anachronistic they may be. Are biblical scholars, historians and archaeologists sufficiently self-reflective and selfcritical to allow ancient realities, whether religious or not, to have operated according to standards, rules, and assumptions that differed radically from the scholars' own, when these scholars understand themselves as standing in some tradition-historical continuity with their object of study (above, Question 4) - however that continuity may be conceptualized in religious, philosophical, moral, or historical terms? ${ }^{13}$

10 W. F. Albright, From the Stone Age to Christianity: Monotheism and the Historical Process ( $2^{\text {nd }}$ ed.; Baltimore: Johns Hopkins, 1946 [orig. 1940]), several times republished.

11 D. R. Hillers, "Analyzing the Abominable: Our Understanding of Canaanite Religion," Jewish Quarterly Review 75 (1985): 253-269.

12 See for instance Bet Alpert Nakhai, Archaeology and the Religions of Canaan and Israel (ASOR Books 7; Boston: American Schools of Oriental Research, 2001), where, as far as I can see, the plural serves essentially to distinguish a "religion of Canaan" from a "religion of Israel," amounting to two clearly discrete entities. Interestingly enough, the original Ph.D. dissertation (University of Arizona, 1993) was entitled Religion in Canaan and Israel: An Archaeological Perspective, where "religion" identifies the general subject matter to be investigated.

13 That assumptions of continuity also have a political dimension in $20^{\text {th }}$ and $21^{\text {st }}$ century scholarship seems obvious, and has been critically addressed in a number of publications. See most recently, E. Pfoh and K. W. Whitelam (eds.) The Politics of Israel's Past: 
Based on ever-increasing archaeological and epigraphical data, as well as on comparative evidence from neighboring regions, religio-historical research of the last decades has challenged scholarly reconstructions of "ancient Israel" and its religion that duplicated or paraphrased biblical historiography. It has produced alternative narratives that increasingly attend not only to differences between religious traditions and social groups, but also to the differences within them. Such alternative reconstructions often operate with concepts and taxonomies borrowed from the social sciences. For instance, one rather influential distinction introduced in the late 1960s was that of state vs. tribe. It has successfully drawn scholarly attention to issues including different forms of social organization, power and authority, and the control of economic resources. Likewise, the concept of "dimorphic societies," ${ }^{14}$ which is based on the division between sedentary and nomadic populations, contributed to theories about Levantine societies as well, including early Israelite society. The problem is that some scholars used it along established, dichotomized lines.

Readers of $\mathrm{HeBAI}$ are well acquainted with the following binary classification, which cannot be attributed to one particular school of thought but reflects a kind of communis opinio that dominated biblical studies and "biblical archaeology" during most of the $20^{\text {th }}$ century:

core

sedentary

agriculture

stratified society

nature / myth

circular time and worldview

fertility cults

polytheism

temples

iconic representations

$\cdots$

Canaan

\author{
periphery \\ nomadic \\ herding \\ egalitarian society \\ history \\ linear time and worldview \\ God active in history \\ monolatry or monotheism \\ open-space sanctuaries \\ aniconism \\ $\ldots$ \\ Israel
}

The Bible, Archaeology and Nation-Building (The Social World of Biblical Antiquity, Second Series 8; Sheffield: Phoenix Press, 2013). While I consider this a particularly sensitive aspect of the overall topic under discussion here, I did not want it to be the primary focus of our seminar. Discussions on politics easily lead to taking sides beyond the academic argument, whereas the main interest of our seminar was critical reflection sine ira et studio of basic epistemological and theoretical issues.

14 M. B. Rowton, "Dimorphic Structure and Topology," Oriens Antiquus 15 (1976): 17-31. 
It immediately springs to mind for any critical observer that these two columns cannot and do not represent discrete, consistent, self-contained, and historically documented systems. What makes such tables attractive to many is the simplifying power of binary classification. One can hardly deny that such binaries, whether based on social-scientific typology, ideological concerns, or religious belief continue to haunt the historical imagination of many students of the Hebrew Bible and ancient Israel.

Beginning in the late 1970s, scholars grew acquainted with another binary: "official" vs. "popular" (or "folk") religion. The former was thought to have prepared the groundwork for what would later become the normative essence of Israelite religion, while the latter was generally considered more flexible, syncretistic, less controlled by priests or prophets, and open to a diversity of beliefs and practices in society (esp. towards women, extended families and patrimonial communities). Not surprisingly, then, it became a new label for what formerly had been called Canaanite religion. ${ }^{15}$ Some scholars preferred the distinction of "establishment" vs. "tolerated non-conformist" cultus, ${ }^{16}$ while still others focused on "official religion" vs. "personal," "family" or "private" religion (or even piety). ${ }^{17}$ These attempts at reclassification may have freed much of our sources from undue normative expectations and thus allowed for a better understanding of ancient Israelite religion. Still, in hindsight, is it not remarkable that most of these reclassifications continue to operate along binary divisions? To be sure, binary classifications may serve a heuristic purpose in scholarly discussion, but we should be aware that they may favor oversimplified views of a social field that must have been composed of much more complex, stratified, and contextually diverse realities.

15 Somewhat extreme examples are E. Stern's "Pagan Yahwism: The Folk Religion of Ancient Israel," Biblical Archaeology Review 27 (2001): 21-29; or with a somewhat different normative agenda, W. G. Dever's Did God Have A Wife? Archaeology and Folk Religion In Ancient Israel (Grand Rapids: Eerdmans, 2005).

16 J. S. Holladay, "Religion in Israel and Judah Under the Monarchy: An Explicitly Archaeological Approach," in Ancient Israelite Religion: Essays in Honor of Frank Moore Cross (ed. P. D. Miller, P. D. Hanson and S. D. McBride; Philadelphia: Fortress Press, 1987), 249-299.

17 R. Albertz, Persönliche Frömmigkeit und offizielle Religion: Religionsinterner Pluralismus in Israel und Babylon (Calwer Theologische Monographien 9; Stuttgart: Calwer, 1978); K. van der Toorn, Family Religion in Babylonia, Syria, and Israel: Continuity and Change in the Forms of Religious Life (Studies in the History and Culture of the Ancient Near East 7; Leiden: Brill, 1996). 


\section{How diverse were ancient Israelite and Judahite religion(s)?}

The basic questions at issue, therefore, are as follows: How do scholars measure, conceptualize and represent cultural diversity - in our case among the religious practices, beliefs and social arrangements within a particular society or socio-cultural aggregate (e.g., kinship group, town, region, polity)? How do they measure, conceptualize and represent that aggregate's features and diversity in comparison to those observed in neighboring aggregates? And how many different units, aggregates or levels do scholars construe when studying society, culture and religion in a particular geographical area (in our case, the southern Levant)? A subsequent question would be, What role may the taxon "Israelite" (and similar taxa based on other ethnonyms) play in scholars' organization of the material? My personal impression is that most scholars interested in "ancient Israel" (archaeologists, historians, biblical scholars, etc.) and "ancient Israelite religion" tend to construe the object of their research first on the basis of historical-geographical considerations, assuming that whatever remains are discovered within what was once the territory of Iron Age II Israel should be considered to reflect "ancient Israelite religion." Once considered Israelite on territorial grounds, scholars turn this evidence into something culturally Israelite and, if considered peculiarly different from comparable evidence from other areas, attribute to it a particular status of marking Israelite identity. Afterwards, it is related to biblical texts in some way or another, since these texts are considered important witnesses for "ancient Israel." By contrast, when particular features do not conform with normative assumptions on "ancient Israelite" culture and religion, the evidence is either pressed in a sense that will bring it into conformity with prior assumptions ${ }^{18}$ or it is conceptually eliminated through ascribing it to an ethnic "other," foreign influence, or the like. ${ }^{19,20}$ In con-

18 This seems to be the logic at work, for instance, in Y. Garfinkel's interpretation of the Qeiyafa shrine models in terms of ancient Israelite aniconism. See Y. Garfinkel and S. Ganor, "Cult in Khirbet Qeiyafa from the Iron Age IIa - Cult Rooms and Shrine Models," in New Studies in the Archaeology of Jerusalem and its Region 6 (2012): 50-65 (Hebrew); Y. Garfinkel and Madeleine Mumcuoglu, "Triglyphs and Recessed Doorframes on a Building Model from Khirbet Qeiyafa: New Light on Two Technical Terms in the Biblical Descriptions of Solomon's Palace and Temple," Israel Exploration Journal 63 (2013): 135-163.

19 Think of the difficulty scholars experience when trying to conceive of "genuinely Israelite" workmanship (admittedly, an ambiguous concept requiring further elaboration) in discussions about the Samaria ivories. See C. Uehlinger, "Die Elfenbeinschnitzereien von Samaria und die Religionsgeschichte Israels: Vorüberlegungen zu einem Forschungsprojekt," in Crafts and Images in Contact: Studies on Eastern Mediterranean Art of the First Millennium bce (ed. C.E. Suter and C. Uehlinger; Orbis Biblicus et Orientalis 
trast again, remains discovered outside the territory of monarchic Israel or Judah are often automatically considered irrelevant and excluded from historical research on ancient Israelite society, culture and religion even when they might well have some potential to illuminate aspects of ancient Israelite cultural and religious history as well. ${ }^{21}$ In other words, scholars often work with implicit binaries (Israelite vs. non-Israelite; Israelite vs. Philistine; Israelite vs. Edomite; etc.) even where such binary classification is neither required nor justified. Since classifications based on political entities and/or "national" territories have become the dominant rule in ancient Levantine archaeology, epigraphy, and history, scholars have built new and illegitimate walls of conceptual and taxonomic division even where binary classifications should have no say.

Some further questions may help bring this point into focus. What do ritual installations and artifacts discovered at various Iron Age II urban sites, in what was once the territory of the northern kingdom of Israel (e. g., Hazor, Megiddo, Tel Rehov, Samaria, Ta anach and others) tell us about the diversity of religious beliefs and practices among the people who inhabited Iron Age II Israel? Should we call all these people "Israelites," and to what extent and in what sense should all of them be designated as remains of ancient Israelite religion? Can we legitimately speak of an ancient Israelite religion in the singular, given the large variety of features and contexts? Or should we instead

210; Fribourg: Academic Press, 2005), 149-186. For a slightly different approach that to some extent relativizes the ethnic or polity-related background of the workmen, see C. E. Suter, "Luxury Goods in Ancient Israel: Questions of Consumption and Production," in Proceedings of the 6th International Congress on the Archaeology of the Ancient Near East (...). Vol. 1: Near Eastern Archaeology in the Past, Present and Future (...). Visual Expression and Craft Production in the Definition of Social Relations and Status (ed. P. Matthiae et al.; Wiesbaden: Harrassowitz, 2010), 993-1002; idem, "Images, Tradition, and Meaning: The Samaria and Other Levantine Ivories of the Iron Age," in A Common Cultural Heritage: Studies on Mesopotamia and the Biblical World in Honor of Barry L. Eichler (ed. G. Frame et al.; Bethesda: CDL Press, 2011), 219-241.

20 On the other hand, in more "revisionist" studies, the same approach may operate to criticize the assumption of Israelite peculiarities or to deny them altogether, at least for the earlier phases of the Iron Age. I recognize such a logic in some of my own earlier work and think that it should be "handled with care." See C. Uehlinger, "Anthropomorphic Cult Statuary in Iron Age Palestine and the Search for Yahweh's Cult Images," in The Image and the Book: Iconic Cults, Aniconism, and the Veneration of the Holy Book in Israel and the Ancient Near East (ed. K. van der Toorn; Contributions to Biblical Exegesis and Theology 21; Leuven: Peeters, 1997), 97-156.

21 Think of, e.g., Temple 650 of Ekron, which is not only a magnificent witness to royal, official and public religion in a major Philistine city, but also can also be related per analogiam to the study of royal temple patronage in other contexts, including the Bible. Or consider the open air sanctuary of Horvat Qițit, which was clearly located within the reach of the late Iron II Judahite state. 
use the plural and address those many different features and contexts as the remains of "The Religions of Ancient Israel," as Z. Zevit suggests in his masterful synthesis on ancient Israelite and Judahite religion(s)? ${ }^{22}$

One should of course ask similar questions for other regions and sites as well. What do ritual installations and artifacts discovered in what was once Philistine territory (e.g., at Ashkelon, Ekron, Gat, Yavneh, etc.) tell us about the diversity of religious beliefs and practices among the inhabitants of the southern coastal plain of Palestine during the Iron Age II? To what extent and in what sense should they be designated as remains of "ancient Philistine religion?" Given the variety of features and contexts, can we legitimately speak of an "ancient Philistine religion" in the singular? Or should we use the plural instead and address those features and contexts as remains of ancient Philistine religions in the plural (see below)?

\section{Was "Israelite" or "Judahite" religion in the Iron Age II distinctive as such? How can the rise of distinctiveness be comprehended historically?}

During the last decades, increasingly fine-grained research in both biblical studies and the history and archaeology of the southern Levant have demonstrated how much the culture and religion of ancient Israel and Judah were part and parcel of their Near Eastern, Levantine, "West Semitic" or "Canaanite" environment. ${ }^{23}$ As already mentioned, one of the most important factors in reconceptualizing ancient Israelite religion was the $20^{\text {th }}$ century discovery of ancient Near Eastern literary corpuses and archives alongside a steadily growing epigraphic record from the Levant, especially the texts from Mari, Ugarit, and Emar. If early discoveries and decipherments of texts from Ugarit may first have confirmed previously held notions of Canaanite otherness, scholars' growing acquaintance with an expanding corpus of ancient Near Eastern texts, once taken as the "context of scripture,"24 has led to a generally shared recognition of ancient Israel's embeddedness in its West Semitic cultural and religious setting. This recognition has considerably reduced

22 Z. Zevit, The Religions of Ancient Israel. A Synthesis of Parallactic Approaches (New York: Continuum, 2001). The plural was echoed in R. S. Hess, Israelite Religions: An Archaeological and Biblical Survey (Grand Rapids: Baker, 2007).

23 M. D. Cogan, "Canaanite Origins and Lineage: Reflections on the Religion of Ancient Israel," Ancient Israelite Religion: Essays in Honor of Frank Moore Cross (ed. P. D. Miller, P. D. Hanson and S. D. McBride; Philadelphia: Fortress Press, 1987), 115-126.

24 See above, n. 8. 
the perception of ancient Israelite religion as essentially distinctive, to the extent that some scholars now argue that Iron Age Israel was no different at all from "Canaanite" or "West Semitic" religion. Most contemporary historiographies consider ancient Israel or Judah's so-called "pre-exilic" religion as one variant among other West Semitic religions ${ }^{25}$ of the first millennium B.C.E. These scholars question or even emphatically deny that there could have been cultural and/or conceptual differences in practice or worldview between various groups, regions, or "nations" during the first half of the first millennium B.C.E. (i. e., Iron age II), and they tend to attribute any distinctive feature in biblical religion to late (i. e., exilic or post-exilic) developments.

In my personal view, theories risk oversimplifying the complexities of the historical process when they (1) operate with a sharp distinction between "pre-exilic" and "post-exilic" Israelite/ Judahite religion; (2) claim that preexilic Israelite/Judahite religion was entirely homologous to other southern Levantine religions; whereas they (3) claim that post-exilic Judahite/ early Jewish religion differed significantly from those religions. Paradoxically, such theories postulate a high degree of social dynamics for the Persian period, two centuries during which the Levant was controlled by the same imperial power, but they have little to say about social dynamics and change during the Iron Age II, a time during which the southern Levant was relatively fragmented politically and territorially, witnessing several changes of macro-political control that were accompanied by substantial reorientations economically and macro-culturally. By emphasizing the disruptive event of the Babylonian exile during the $6^{\text {th }}$ century B.C.E. - what about the earlier deportations and accompanying population changes during the $9^{\text {th }}$ and late $8^{\text {th }}$ centuries? - such theories seem ultimately to rely on the biblical master narrative's periodization scheme, which historians should handle critically. Interestingly, they again operate with a binary division, now construed temporally (i.e., pre- vs. post-exilic). Yet luckily enough, new documents are now available for reinterpreting the end of monarchic Judah and the exile of

25 When using the concept of "West Semitic religions" in the plural, scholars usually refer to a number of distinct belief systems, which they relate to first millennium "peoples," "polities," or "nations" (concepts which are all anachronistic, though related to an established convention in Bible translation): Ammonite, Aramean, Edomite, Moabite, Philistine, Phoenician, etc. Whether ethnonyms are appropriate classifiers for distinguishing one southern Levantine religion from another is questionable. The distinction only makes sense on the level of discrete polities in relation to territorial control and a system of tax collection and ritual offerings to a privileged "national" deity associated with the welfare of the royal house. From the perspective of comparative religion, the ethnic distinction does not justify the assumption of discrete symbol systems or "religions." 
Judahite elites not only in terms of disruption, but equally of accommodation and thus a particular phase of an ongoing historical continuum.

The more diverse, the less distinctive?

As we have seen, scholarly narratives that emphasize the difference and distinctiveness of Iron age II "Israelite" religion (traditionally, a singular noun) have gradually been replaced by narratives that stress commonalities and similarity, if not a basic congruence or even sameness of Israelite and Judahite religion(s), on the one hand, and "Canaanite" or "West Semitic" religion(s), on the other. This new view that sees ancient Israelite and Judahite religion(s) as subsets of "West Semitic" religion(s) relies on archaeology and, most heavily, on epigraphy from the southern Levant and other regions. Particularly the inscriptions from Kuntillet 'Ağrūd and from Khirbet el-Qom have had the strongest effect on the scholarly community, prompting the aforementioned reevaluation. At the same time, however, ongoing archaeological exploration is producing ever-increasing evidence that points toward local and regional peculiarities, as well as a considerable degree of diversity in southern Levantine societies. The resultant, twopronged epistemological paradox has rarely been noticed: On the one hand, the new consensus has reduced (to be sure, with good reasons) religious difference between Israel, Judah and their neighbors, and has produced a kind of all-inclusive, homogeneous "West Semitic" type-religion. But on the other hand, it becomes increasingly obvious that this "West Semitic" matrix is really nothing but a scholarly model, and that the bigger challenge lying before us is to reconceptualize distinctiveness in terms of diversity without neglecting the equally obvious, and plausible, commonalities.

Upon recognizing this paradox, it seems worthwhile to pause for a moment of critical, disciplinary self-reflection and to address a few theoretical and methodological questions:

(a) Is the change of emphasis in the way scholars perceive, construct, and evaluate ancient Israelite and Judahite religion(s) due to an increase of relevant data and/ or source materials? Is it well supported by an increasing and unambiguous wealth of data? Or are we witnessing a change in scholarly discourse, based on new criteria for evaluation and plausibility rather than compelling evidence?

(b) To what degree is the change of emphasis related to a difference in focus and possibly to alternative hierarchies or taxonomies in the selection of data (e.g., privileging "primary evidence" like archaeology and epigraphy over "secondary" biblical texts; attending to social-functionalist rather than ethnic descriptors; etc.)? 
(c) To what degree is the change of emphasis due to changing theoretical and/or methodological premises and assumptions, such as

- different conceptions of religion(s) that stress mediated practices rather than belief or "symbol systems" (C. Geertz);

- an anthropological and functionalist focus that stresses the importance of local ecological, economic, and social conditions in the development of religious practices and worldviews;

- sociological approaches that emphasize social diversity, the coexistence within societies of different groups and worldviews, and that are sensitive to the differing religious "needs" of people according to social location (e.g., class, economic status, activity or profession, gender, etc.)?

(d) One should also ask whether this change in scholarly emphasis has been affected, if not driven by, extra-academic developments in the contemporary world, some of which this essay has already mentioned:

- In Israel, the political and social environment of academic research on the history of the country in the first millennium B.C.E. is changing. For the pioneering generations of archaeologists and historians, it seemed necessary and plausible that archaeological discoveries would match and support the biblical narrative. But in present day Israel, this is no longer the case, and the field tends to be divided (no doubt in an oversimplified manner). Coming from one angle are scholars with a clear hierarchy between archaeological and biblical scholarship, according to which archaeology is always first and the Bible second (if it has anything at all to say). From another angle are scholars who continue to hold both ends together, but with an inclination toward prioritizing archaeology. And from yet another angle are scholars for whom harmonizing archaeology and the Bible, if not proving the Bible's historicity, still seems to be a valid task and a major aim.

- In Europe and the USA, socio-political ideologies that are ultimately related to biblical ideals (dialectic, emancipatory, egalitarian, etc.) have gradually been abandoned since the end of the Cold War. Concerns with economics, ecology, and sustainability have moved to the forefront of political debates and decisions. The growing impact on Western societies of issues regarding migration and mobility has raised public sensitivity for and debate about multiculturalism. At the same time, ethnic pluralization has led globally to an increase in "identity" talk and to tensions, as well as to the rise of new strategies for "diversity management."

- On a global scale, but especially in countries belonging to the so-called Western hemisphere, there are ongoing processes of secularization and pluralization of religious practices and worldviews. These processes have resulted in a softening of distinctive knowledge on religion, let alone a par- 
ticular religion as one's own heritage or belonging. At the same time and increasingly, religious actors in Western countries stress the importance of inter-religious dialogue, which produces a peculiar and, again, softening effect on religious truth claims. Claims that one religion is superior to others are no longer widely recognized in Western societies. In other words, in the religious domain of Western societies (i.e., the societies where most of the relevant scholarship is produced), distinctiveness has largely been replaced as a subject of public discourse by talk of commonalities and diversity.

Taken together, it seems after all that scholarly reconstructions of the history of ancient Levantine religion(s) during the Iron age II were and continue to be children of their own time and context. In a heavily ideology-driven age, the master narrative and "paradigm" emphasized the distinctiveness of Israel's religion from its inception or, at least, from an early point in its history (think of studies charging the earliest history of Israel with all the egalitarian pathos of post-World War II liberation movements). In contrast, more recent discussions insist on cross-cultural commonalities, whether in content or in function, and stress the significance of intra-societal diversity and even pluralism (religious or otherwise).

Once scholarship's largely conjunctural framework is recognized, one may point to a number of problems that have not yet found satisfactory answers:

(a) Both the old and new approaches seem to have difficulty in bringing difference and similarity, distinctiveness and diversity, into reasonable and adequate balance. While earlier approaches seem to have unduly privileged aspects of difference, more recent ones seem to underestimate, downplay or simply ignore observable features of difference - perhaps because they do not allocate them to the appropriate social aggregate (that is, a local or regional rather than a "national" unit).

(b) Both the old and new approaches seem to have difficulty in developing a critical and truly historical understanding of the formation of distinctiveness and diversity in the Southern Levant's religious history, especially during the Iron Age II. Needless to say, such a critical understanding should not focus exclusively on ancient Israel, or ancient Israel and Judah, but rather should raise the same questions with regard to other polities, regions and societies of the southern Levant in their own right.

Upon acknowledging these difficulties, we may well need to reconsider and possibly revise some long-established scholarly assumptions and habits. For a start, we should critically reconsider the following three issues:

(1) whether or not it might be appropriate for the period under consideration to conceptualize differences in the material record in terms other than ethnic or "national" denominations - especially when there is no apparent 
need for them or when their application produces no additional, historical explanatory value;

(2) what other parameters would seem more appropriate for describing diversity and commonality among and within ancient Levantine religion(s);

(3) to what extent scholars with particular interest in Israel and Judah should not only address and classify differences between northern ("Israelite") and southern ("Judahite") developments, but also should pay closer attention to a still larger spectrum of regional diversity, whose designation as "Israelite" or "Judahite" does not seem particularly helpful.

\section{Beyond popular religion: social diversity and ancient Israelite religion(s)}

Over the last two decades, the "popular religion" paradigm has gradually been replaced by the concept of "family and household religion." ${ }^{26}$ Scholars have also challenged the binary of "official" vs. "popular," suggesting more refined social taxonomies in its stead. The impressive synthesis recently offered by R. Albertz and R. Schmitt distinguishes no less than eight types (and additional sub-types) of cultic arrangements in ancient Israelite society: ${ }^{27}$

I. Domestic cult: (A) usual domestic cult with the nuclear or extended family as carrier group; and (B) large-scale domestic cult or shrine

II. Work-related cults: (A) small-scale, inner circle, nuclear family; and (B) large-scale, inner and middle circles, extended/joint family and wider kin

III. Neighborhood cult installations or shrines (medium circle, ranging from nuclear or extended family to co-residential lineage and neighborhood)

IV. Places for the cult of the dead (medium circle)

26 J. Bodel and S. M. Olyan (ed.), Household and Family Religion in Antiquity (Oxford: Blackwell Publishing, 2008); R. Albertz and R. Schmitt, Family and Household Religion in Ancient Israel and the Levant (Winona Lake: Eisenbrauns, 2012); R. Albertz, Beth Alpert Nakhai, S. M. Olyan and R. Schmitt (ed.), Family and Household Religion: Toward a Synthesis of Old Testament Studies, Archaeology, Epigraphy, and Cultural Studies (Winona Lake: Eisenbrauns, 2014).

27 Albertz and Schmitt, Family and Household Religion, esp. 480-482; R. Schmitt, "A Typology of Iron Age Cult Places," in Family and Household Religion: Toward a Synthesis of Old Testament Studies, Archaeology, Epigraphy, and Cultural Studies (ed. R. Albertz et al.; Winona Lake: Eisenbrauns, 2014). 
V. Village sanctuaries, outer circle, with co-residential lineage and / or the local community as carrier group: (A) shrines; (B) open-air cult places; and (C) gate sanctuaries

VI. Palace shrines (an official variant of large-scale domestic cult practice, with military and administrative elites serving as carrier group)

VII. Regional sanctuaries, with priests maintaining the cult and regional communities as carrier group: (A) shrine/temple; and (B) open-air

VIII. Supra-regional temples of the official cult, supported by royalty and maintained by a priesthood

The model's criteria are based on (a) social stratification - from household or family as the most basic social unit to state and royalty as the hierarchically highest level of social aggregation, ${ }^{28}$ and (b) the degree of social outreach and relevance of a particular ritual setting for a specific target or carrier group. ${ }^{29}$ Further archaeological research will show whether Schmitt's classification, which involves no less than 13 type units, can be applied usefully to the evidence on the ground, or whether the evidence usually resists placement into any one category. ${ }^{30}$

Obviously, Albertz and Schmitt's massive synthesis represents an important step toward a refined analysis of the relevant archaeological evidence and its explanation in terms of social and cultural history. I also consider it appropriate that Albertz and Schmitt approach their topic with ancient Israel and the Levant in mind, though "ancient Israel" is clearly the focus of their book, where there seems to be a lack of discussion about what exactly they mean by "ancient Israel." Their book also includes sophisticated methodological reflection and discusses key concepts such as "family," "household," and "internal religious pluralism." ${ }^{11}$ However, Albertz and Schmitt seem to

28 At both ends, one could add yet another "level": at the grassroots or bottom level, the individual and his or her "personal" set of religious practices and beliefs (which Albertz and others have addressed in terms of "personal piety"); and at the top level, imperial superstructures which in the ancient Near East relied heavily on religious legitimation. The temple of Harran provides a particularly interesting example of such an overarching religious superstructure, whose significance reached far beyond North Syria and well into the southern Levant.

29 Interestingly, gender diversity does not seem to directly impact the typology, which contrasts with other reconstructions. See, e.g., C. Meyers, Households and Holiness. The Religious Culture of Israelite Women (Minneapolis: Fortress Press, 2005); idem, Rediscovering Eve. Ancient Israelite Women in Context (New York: Oxford University Press, 2013).

30 Schmitt designates case examples for each type and sub-type, but his typology might actually work better when taken in terms of theoretical "ideal types" in a Weberian sense.

31 Notably, this last concept seems in their understanding to designate actual diversity rather than pluralism, which, in my view, would imply a normative position on the 
have left open the question raised above about whether and how particular sets of evidence should be conceptualized in terms of a particularly Israelite interpretative horizon.

The 2010 edited volume by J. Barton and F. Stavrakopoulou represents what is perhaps the most ambitious recent attempt explicitly to address diversities (in the plural) within the religion(s) of ancient Israel and Judah. ${ }^{32}$ The book is organized in four parts that are entitled (I) "Conceptual Diversities;" (II) "Socio-Religious Diversities;” (III) "Geographical Diversities;” and a "Postscript" in which Barton reflects upon "the complex relationship between the Hebrew Bible and the religious past it seeks to portray." 33 Part I "seeks to deconstruct persistent and misleading assumptions about Israelite and Judahite religions and reconstructs Israelite and Judahite perceptions of the nature of the religious world." ${ }^{34}$ S. Niditch ${ }^{35}$ discusses various biblical accounts of direct experience of the divine and concludes that there was an obvious diversity which cannot and should not be reduced to any sharp distinction between "official" cult and "popular" religion, a dichotomy also criticised in Stavrakopoulou's article. ${ }^{36} \mathrm{H}$. Niehr ${ }^{37}$ questions both the concepts and the opposition of "Israelite" vs. "Canaanite" religion. Echoing M. Coogan's characterization of "Israelite religion as a subset of Canaanite religion," 38 Niehr argues that "Israelites" were themselves "Canaanites" and that, before the $6^{\text {th }}$ century, Israelites and Judahites were therefore "polytheists like any other Canaanites." ${ }^{39}$ According to Niehr, "each West Semitic reli-

legitimacy of diversity - something we can neither recognize nor take for granted with regard to the archaeological material or ancient Levantine societies.

32 F. Stavrakopoulou and J. Barton (ed.), Religious Diversity in Ancient Israel and Judah (London: T\&T Clark, 2010).

33 Ibid., 2.

34 Ibid.

35 "Experiencing the Divine: Heavenly Visits, Earthly Encounters and the Land of the Dead," in Religious Diversity in Ancient Israel and Judah (ed. F. Stavrakopoulou and J. Barton; London: T\&T Clark, 2010), 11-22.

36 “'Popular' Religion and 'Official' Religion: Practice, Perception, Portrayal,' in Religious Diversity in Ancient Israel and Judah (ed. F. Stavrakopoulou and J. Barton; London: T\&T Clark, 2010), 37-58.

37 “'Israelite' Religion and 'Canaanite' Religion," in Religious Diversity in Ancient Israel and Judah (ed. F. Stavrakopoulou and J. Barton; London: T\&T Clark, 2010), 23-36.

38 M. D. Cogan, "Canaanite Origins and Lineage: Reflections on the Religion of Ancient Israel," in Ancient Israelite Religion: Essays in Honor of Frank Moore Cross (ed. P. D. Miller, P. D. Hanson and S. D. McBride; Philadelphia: Fortress Press, 1987), 115126, here 115.

39 That the focus should be on monotheism vs. polytheism - that is, diversity and plurality in the conceptualization of the divine - points to the haunting effectiveness of theological concerns even among writers one could characterize as critical revisionists. 
gion has its own characteristics" and "some differences between Israel and Judah and their neighbours can be discerned." 40 But Niehr's discussion does not identify them. Instead, he stresses how much any feature discernible in either Israelite or Judahite religion finds parallels in other West Semitic religions or in ancient Near Eastern religion in general.

Part II addresses socio-religious diversities, where the editors "again [seek] to demonstrate that the religions (sic) of ancient Israel and Judah can best be understood as a series of spectra, rather than in terms of either/or distinctions." ${ }^{11}$ N. Wyatt writes about "Royal Religion in Ancient Judah," 42 though his focus on Judah does not imply distinctiveness, since he reconstructs Judahite royal religion as having operated according to the same rules as royal religion in Late Bronze age Ugarit. ${ }^{43}$ P. Davies ${ }^{44}$ discusses urban vs. rural religion, stressing that the two are distinguished in texts (and scholarly reconstruction) on the basis of cultural, theological and ideal criteria, but that the city and country actually had a symbiotic relationship. C. Meyers' 45 and R. Albertz's ${ }^{46}$ complementary essays on household and personal religion are best read alongside each other. An interesting question that these two authors do not explicitly address is how much diversity would have been allowed within the ancient religion(s) of households and families between individual family members. ${ }^{47}$

D. Edelman ${ }^{48}$ examines biblical and archaeological evidence of temples, shrines, open-air sanctuaries, and other cultic sites beyond Jerusalem and

40 H. Niehr, “Israelite' Religion and 'Canaanite' Religion," in Religious Diversity in Ancient Israel and Judah (ed. F. Stavrakopoulou and J. Barton; London: T\&T Clark, 2010), 30, 32.

41 J. Barton and F. Stavrakopoulou, "Introduction," in Religious Diversity in Ancient Israel and Judah (ed. F. Stavrakopoulou and J. Barton; London: T\&T Clark, 2010), 4.

42 N. Wyatt, "Royal Religion in Ancient Judah," in Religious Diversity in Ancient Israel and Judah (ed. F. Stavrakopoulou and J. Barton; London: T\&T Clark, 2010), 61-81.

43 I again point out that such a claim can only make sense to the historian if we admit that we are dealing with "ideal types," which, by definition, are scholarly models.

44 P. Davies, "Urban Religion and Rural Religion," in Religious Diversity in Ancient Israel and Judah (ed. F. Stavrakopoulou and J. Barton; London: T\&T Clark, 2010), 61-81.

45 C. Meyers, "Household Religion," in Religious Diversity in Ancient Israel and Judah (ed. F. Stavrakopoulou and J. Barton; London: T\&T Clark, 2010), 118-134.

46 R. Albertz, "Personal Piety," in Religious Diversity in Ancient Israel and Judah (ed. F. Stavrakopoulou and J. Barton; London: T\&T Clark, 2010), 135-146.

47 The question of individual options is heavily debated in recent studies on Greek and especially Roman religion, which are admittedly different contexts in terms of space, time, and social fabric.

48 D. Edelman, "Cultic Sites and Complexes Beyond the Jerusalem Temple," in Religious Diversity in Ancient Israel and Judah (ed. F. Stavrakopoulou and J. Barton; London: T\&T Clark, 2010), 82-103. 
its temple. The first inventory based on biblical texts may remind readers that, normative agendas notwithstanding, the biblical record as a whole is far from being homogenous or hegemonistic and provides a wealth of information about cultic sites and complexes beyond the Jerusalem temple. In her article's second part, Edelman discusses artifactual evidence, which leads her to theorize diversity in terms of four types of shrines that can be functionally and topologically distinguished: intramural local shrines and temples (in cities and towns); gate shrines; cultic complexes in forts; and shrines associated with trade. Defined according to spatial location and socio-political function, these types do not square easily with those of Albertz and Schmitt. But since Edelman's typology is no less plausible than theirs, it draw our attention to the fact that typologies are indeed scholarly constructs, developed in a theoretical framework to answer particular questions and to produce historical explanations rather than reconstruct historical reality as such.

The subject of Part III is geographical diversities. L. L. Grabbe ${ }^{49}$ scrutinizes ancient sources to see whether they have something to say about Yahweh outside (Israel and ${ }^{50}$ ) Judah. Focusing on the southern Levant, J. M. Hutton discusses "Southern, Northern and Transjordanian Perspectives." ${ }^{51} \mathrm{He}$ uses the term "Israelian" for populations and forms of religion attested in the North (that is, the northern kingdom of Israel) and "Judahite" for the South, which would make these terms geographical markers like "Transjordanian." But he also makes it clear (in line with the book as a whole) that he is mainly interested in (northern, southern, and Transjordanian) "Israelites." Hutton is one of the rare authors to introduce his paper with explicit theoretical considerations, pointing to the importance of geography and topology for the genesis of social and cultural formations. Applying the analogy of microclimates to the latter, as well as to religion, he suggests a three-level model to distinguish "small-scale local religious expressions," which he designates micro-religions, from regionally and politically defined macro-religions, which he argues "constitute sub-units of what might be termed pan-Israelite

49 “"Many Nations Will Be Joined to Yhwh in That Day': The Question of Yhwh Outside Judah," in Religious Diversity in Ancient Israel and Judah (ed. F. Stavrakopoulou and J. Barton; London: T\&T Clark, 2010), 175-187.

50 The title suggests a focus that is not fully borne out by the article. Its first section is actually entitled "Yhwh outside Israel/Judah?" and discusses texts from Ebla, Mari, Ugarit, as well as Assyrian inscriptions referring to North-Syrian rulers (Azriyau [formerly thought to be from Ya'adi] and Yaubi'di of Hamath).

51 J.M. Hutton, "Southern, Northern, and Transjordanian Perspectives," in Religious Diversity in Ancient Israel and Judah (ed. F. Stavrakopoulou and J. Barton; London: T\&T Clark, 2010), 149-174. 
religion." ${ }^{2}$ The distinction between micro- and macro-religion(s) is helpful and provides a good starting point for my last question - namely, whether one should speak of, say, ancient Israelite (or Israelian), Judahite, or Philistine religion in the singular or, instead, of religions in the plural.

\section{Religion or religion(s) in ancient Israel, Judah and the southern Levant?}

When Zevit published his massive 2001 volume entitled The Religions of Ancient Israel: A Synthesis of Parallactic Approaches, it produced considerable surprise in the scholarly community. Not only did more than one nonAnglosaxon scholar have to look up the meaning of "parallactic" to tell what it could mean when applied to the history of ancient Israelite religion(s), ${ }^{53}$ but also and especially the plural religions ("a tantalizing element in the book's title" ${ }^{44}$ ) was surprising, since it exposed readers to the possibility (to my knowledge, never before so explicitly conceptualized) that "ancient Israel" may indeed have followed more than one religion. Yet the idea proves less spectacular than it appears at first sight, since the Bible itself is full of narratives, polemics and lamentations that "ancient Israelites" did not always follow the one religion that authors, prophets, or God would have considered best for them. But this was not the intended point of Zevit's title. To the contrary, Zevit used the plural because in his view, "in historical manifestation [...] there was no commonly accepted cultic norm and praxis." Precisely as a means of avoiding the biblical trap and thus "consider[ing] the idealized, Jerusalem perspective of what ought to have been a cultic and behavioral norm for all Israelites 'proper Israelite religion,' and deviations from this 'corruptions," Zevit preferred the plural noun that in his view is "more concrete and historically defensible" than a singular. ${ }^{55}$

52 Ibid., 151.

53 According to one online dictionary, a parallax designates "a change in the apparent position of an object relative to more distant objects, caused by a change in the observer's line of sight towards the object" (http://www.thefreedictionary.com/Parallactic). I found no explanation by Zevit for his particular use of this term, which figures neither in chapter nor section headings nor in the index. But the main justification seems to be the book's aim "to determine what may be known about Israelite religions during the Iron Age, c. 1200-586 bce, through an integration of classified archaeological, epigraphic, and literary data usually considered in isolation" (Zevit, Religions of Ancient Israel, xiv).

54 M. Smith, "Review Article of The Religions of Ancient Israel (...)," Maarav 11 (2004): 145-218, here 157.

55 Zevit, Religions of Ancient Israel, 15. 
M. Smith has pointed out that Zevit's provocative plural does not carry much weight in the subsequent development of his book, ${ }^{56}$ but that it "raises a host of questions about the relative relatedness of different symbolic systems and their different modes of praxis," ${ }^{27}$ among which are the following:

"If there are Israelite religions, then there are various Moabite, Edomite, Ammonite, Phoenician or Philistine religions; analogously, there are different Canaanite religions and not just Canaanite religion. Could one or another of Zevit's Israelite religions be more proximate to one of the non-Israelite religions?"58

I agree with Smith that this issue may indeed be among the most crucial consequences and challenges posed by Zevit's insistence on parallaxis as much as on the plural noun "religions." If the plurality and diversity of sets of evidence indicates many different practices, beliefs and social arrangements, then it may well be that these are not necessarily related to each other by any kind of superimposed structure (such as that provided by a common ethnic, let alone "national" identity or the mere historical fact of being subject to the same political overlord, e. g., a king residing in Samaria or Jerusalem). If correct, they cannot constitute a coherent, larger aggregate such as the concept of "ancient Israelite religion" (understood as an ancient reality as opposed to a scholarly construct) would require. Equally plausible, or even more probable based on the assumption that religion in the southern Levant was fragmented into a variety of local micro- or "meso-religions," ${ }^{99}$ is the idea

56 The same can be said for Hess's book Israelite Religions. It may well be that the pluralization was in both instances related to a general tendency to pluralize, which is observable in recent scholarly discourse in the humanities and social sciences far beyond the disciplines addressed by this journal. Think for example of pluralizations such as Judaisms, Christianities, Islams, and Buddhisms, or monotheisms vs. polytheisms; or of theories on multiple modernities, secularizations, identities, etc. The Sprachspiel of pluralization is clearly en vogue among contemporary scholars, who often (but not always) use it strategically in order to labor a particular discursive field and to produce some effect on their community. Whether the use of the plural diversities in the edited volume by Stavrakopoulou and Barton is part of that tendency or whether it points to the somewhat unstable substructure of a theoretical and conceptual grid under construction remains unclear to me.

57 Smith, "Review Article," 157.

58 Smith, "Review Article," 158. "This question is precluded by Zevit's notion of Israelite ethnicity," which postulates a coherent Israelite collective identity since an early period (Iron Age I; see Zevit, Religions of Ancient Israel, chapter 2, esp. 84-121). See in turn Smith's criticism ("Review Article," 159-175) and concluding comment regarding that chapter: "On the whole, Israelite ethnicity from the Iron I onward, as viewed through biblical texts of the Iron II and later, is a major cornerstone of this intellectual project" (ibid. 175, emphasis added).

59 An intermediate term that Hutton does not use but that, in my view, is essential for grasping systems of only regional outreach, which are not necessarily related to a larger polity. 
that labeling them in ethnic, "national," or political terms often carries little meaning and will not further our understanding of their historical significance within their carrier groups. For example, consider the localized sets of evidence from Tel Rehov: How appropriate is it and what do we gain (or lose) when labelling that evidence "Israelite?" Or consider the cultic artifacts from the Yavneh favissa: Is it appropriate and what do we gain (or lose) when labelling them "Philistine?"

My personal preference and suggestion would be to continue studying religion (singular) in the ancient southern Levant, being fully aware that "religion" is here understood as a theoretical concept designating a particular subject matter for research. Hence, it is nothing more or less than a construct of the scholar in his or her study. ${ }^{60}$ Concepts such as "West Semitic religion" or religion in ancient Israel will continue to make perfect sense when clearly defined and used that way. The singular also seems preferable when a certain type of religion is addressed (e.g. popular, family, or palacerelated royal religion).

In contrast, I hesitate to adopt the plural "religions" and apply it to any discrete set of archaeological or otherwise artifactual evidence, whether micro or meso, as long as I do not know whether it is indeed the unambiguous expression of a meaningfully operating, self-contained entity, of a set of practices and beliefs relatable to a definable social carrier. A particular ritual performed at a city gate does not, in my view, constitute a discrete religion (whether micro or meso) and should not be conceptualized as such. One should not, by the way, overlook that pluralizations of key scholarly concepts paradoxically tend to reify rather than to de-essentialize their objects. In sum, historians of ancient religion who focus their attention on the Iron Age II and the southern Levant are better off not inventing too many different religions and projecting them into that region's past. ${ }^{61}$

60 A classic treatment is J. Z. Smith's "Religion, Religions, Religious," in Critical Terms for Religious Studies (ed. M.C. Taylor; Chicago: The University of Chicago Press, 1998), 269-284; repr. in idem, Relating Religion: Essays in the Study of Religion (Chicago: The University of Chicago Press, 2004), 179-196.

61 My sincere thanks to Phillip Lasater, the editorial assistant of HeBAI and a fine colleague at the University of Zurich, for the patience and careful attention with which he accompanied the gestation of this issue, and not least for his important redactional improvements of this introductory essay. 


\section{Hebrew Bible and Ancient Israel}

Edited by Gary N. Knoppers (Notre Dame IN), Oded Lipschits

(Tel Aviv), Carol A. Newsom (Atlanta GA), and Konrad Schmid (Zürich)

Redaction: Phillip Michael Lasater (Zürich)

Hebrew Bible and Ancient Israel publishes only invited articles. Submission of a paper will be held to imply that it contains original unpublished work and is not being submitted for publication elsewhere. All articles are refereed by specialists. Acceptance for publication will be given in writing. When an article is accepted for publication, the exclusive copyright is granted to Mohr Siebeck for publication in a print and an electronic version. Further information on this and the rights retained by the author can be found at www.mohr.de/hebai. No one may reproduce or distribute the entire journal or parts of it in a print or an electronic version without the publisher's permission. Please contact rights@mohr.de.

Please do not send any unsolicited review copies. The publisher and the editors reserve the right to keep unsolicited books.

\section{Contact address:}

Professor Dr. Konrad Schmid

Theologische Fakultät der Universität Zürich

Kirchgasse 9

CH-8001 Zürich

Switzerland

E-mail: hebai@theol.uzh.ch

\section{Full Text Online}

Free access to the full text online is included in a subscription. We ask institutions with more than 20,000 users to obtain a price quote directly from the publisher. Contact: elke.brixner@mohr.de. In order to set up online access for institutions/libraries, please go to: http://www.ingentaconnect.com/register/ institutional. In order to set up online access for private persons, please go to: http://www.ingentaconnect.com/register/personal

Publisher: Mohr Siebeck GmbH \& Co. KG, Postfach 2040, 72010 Tübingen Can be purchased at bookstores.

(C) 2015 Mohr Siebeck GmbH \& Co. KG, Tübingen

The journal and all the individual articles and illustrations contained in it are protected by copyright. Any utilization beyond the narrow confines of copyright law without the publisher's consent is punishable by law. This applies in particular to copying, translations, microfilming and storage and processing in electronic systems.

Printed in Germany.

Typeset by Martin Fischer, Tübingen.

Printed by Gulde-Druck, Tübingen.

ISSN 2192-2276 (Print Edition)

ISSN 2192-2284 (Online Edition) 


\section{Hebrew Bible and Ancient Israel volume 4(2015), no.1}

\section{Edited by}

Gary N. Knoppers (Notre Dame IN), Oded Lipschits (Tel Aviv), Carol A. Newsom (Atlanta GA), and Konrad Schmid (Zürich)

Hebrew Bible and Ancient Israel is a new, peer-reviewed, quarterly journal focusing primarily on the biblical texts in their ancient historical contexts, but also on the history of Israel in its own right. Each issue has a topical focus. The primary language is English, but articles may also be published in German and French. A specific goal of the new journal is to foster discussion among different academic cultures within a larger international context pertaining to the study of the Hebrew Bible and ancient Israel in the first millennium B.C.E.

Hebrew Bible and Ancient Israel ist eine neue Zeitschrift, die vierteljährlich erscheint und deren Beiträge durch einen Peerreview-Prozess evaluiert werden. Ihr Thema sind die Texte der hebräischen und aramäischen Bibel in ihren historischen Kontexten, aber auch die Geschichte Israels selbst. Jedes Heft wird einen thematischen Fokus haben. Die meisten Beiträge werden in Englisch verfasst sein, Artikel können aber auch auf Deutsch oder Französisch erscheinen. Ein besonderes Ziel der Zeitschrift besteht in der Vermittlung der unterschiedlichen akademischen Kulturen im globalen Kontext, die sich mit der Hebräischen Bibel und dem antiken Israel im 1. Jahrtausend v. Chr. beschäftigen.

\section{Associate Editors (2012-2015)}

Erhard Blum, Tübingen; John Day, Oxford; Louis Jonker, Stellenbosch; John Kessler, Toronto; Jacqueline E. Lapsley, Princeton; Martti Nissinen, Helsinki; Thomas Römer, Paris/Lausanne; Christoph Uehlinger, Zürich; David Vanderhooft, Boston; Nili Wazana, Jerusalem

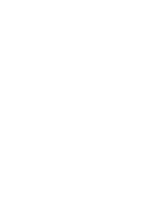

Mohr Siebeck www.mohr.de

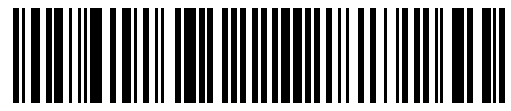

$2192-2276(201503) 4: 1 ; 1-z$ 